\title{
THE ROLE OF MICRO, SMALL, AND MEDIUM ENTERPRISES (MSMES) IN ABSORBING MANPOWER IN CIAMIS DISTRICT
}

\author{
Rifqi Arief Aminullah \\ Institut Agama Islam Darussalam (IAID) Ciamis-Jawa Barat \\ Email: rifqiarief.aminullah@iaid.ac.id \\ Sariyanti \\ Institut Agama Islam Darussalam (IAID) Ciamis-Jawa Barat \\ Husna Lailatul Qadar \\ Institut Agama Islam Darussalam (IAID) Ciamis-Jawa Barat
}

\begin{abstract}
Since the economic crisis that occurred in Indonesia in 1997, many large-scale businesses have stagnated and even stopped their activities. The soaring population growth accompanied by an increase in the labor force creates a very complex problem, namely the increasing number of unemployed. This is due to the uneven distribution of development in all fields so that the availability of employment opportunities is not balanced. However, the Micro, Small and Medium Enterprises (MSME) sector was able to face the crisis. The research method used is descriptive-analytical by conducting research in the industri tahu bulat by CV. Macakal Pangan Sejahtera in Cipaku District, Ciamis Regency. The results showed (1) the absorption of labor by the industri tahu bulat CV. Macakal Pangan Sejahteral in Cipaku District, Ciamis Regency from 2019 reached 250 people, while in 2020 it was 136 people. There was a decrease in the number of employees between 2019 and 2020; and (2) the role of Micro, Small and Medium Enterprises (MSMEs) in the tofu industry CV. Macakal Pangan Sejahtera in the economy in Cipaku District can be seen from its position as a major player in economic activity, a large provider of employment, an important player in the development of local economic activities and community empowerment, the creation of new markets, and a source of innovation.
\end{abstract}

\begin{abstract}
Abstrak
Sejak krisis ekonomi yang terjadi di Indonesia pada tahun 1997 banyak usaha berskala besar mengalami stagnasi bahkan berhenti aktifitasnya. Melonjaknya pertumbuhan penduduk yang diiringi dengan pertambahan angkatan kerja menimbulkan permasalahan yang sangat kompleks yaitu meningkatnya jumlah pengangguran. Hal ini disebabkan karena belum meratanya pembangunan di segala bidang sehingga ketersediaan lapangan kerja tidak seimbang. Akan tetapi, sektor Usaha Mikro Kecil dan Menengah (UMKM) ternyata mampu menghadapi masalah krisis tersebut. Metode penelitian yang digunakan adalah deskriptif-analitis dengan melakukan penelitian di industri tahu bulat oleh CV. Macakal Pangan Sejahtera di Kecamatan Cipaku Kabupaten Ciamis. Hasil penelitian menunjukkan (1) penyerapan tenaga kerja oleh industri tahu bulat CV. Macakal Pangan Sejahtera di Kecamatan Cipaku Kabupaten Ciamis dari tahun 2019 mencapai 250 orang, sedangkan pada tahun 2020 menjadi 136 orang. Terdapat penurunan jumlah karyawan antara periode 2019 dengan periode 2020; and (2) peran Usaha Mikro Kecil dan Menengah (UMKM) industri tahu bulat CV. Macakal Pangan Sejahtera dalam perekonomian di Kecamatan Cipaku dapat dilihat dari kedudukannya sebagai pemain utama dalam kegiatan ekonomi, penyedia
\end{abstract}


lapangan kerja yang besar, pemain penting dalam pengembangan kegiatan ekonomi lokal dan pemberdayaan masyarakat, penciptaan pasar baru, dan sumber inovasi.

Keywords: Unemployment, MSMEs, Labor, Syari’a Economics

\section{Introduction}

The development of Micro, Small and Medium Enterprises (MSMEs) is estimated to be better due to the opening of entrepreneurial opportunities and consolidation among MSMEs in overcoming limited access to capital (Sukamdani, 2001). Since the financial crisis, the MSME sector has continued to run even though it is not supported by appropriate policies from the government or bank credit. MSMEs, which previously relied a lot on government projects, have now turned to businesses that are resistant to crises, such as agro-industry, trade, exports and those based on human resources.

Micro, Small and Medium Enterprises have a very significant contribution towards the stage of economic development in Cipaku District. The most visible role of small and medium enterprises in economic development is in terms of employment. Micro, Small and Medium Enterprises are able to absorb labor because of the characteristics of work in the Micro, Small and Medium Enterprises sector which does not require many requirements as in large companies. With this increasingly healthy and professional MSME sector, economic independence can be realized.

Bank Indonesia tries to understand the problems in efforts to empower MSMEs from various perspectives. Although the focus is on financial and credit aspects, managerial, legal, production, marketing, and labor aspects are not neglected. The interest of MSMEs is still reduced to finance their activities with credit. Therefore, in line with the condition of capital owned by MSMEs, 71 percent still use their own capital. This shows that there is an information gap between MSME knowledge and banking credit products or procedures. In order to bridge this gap, information on the financial condition of customers, an understanding of potential economic sectors and special training for bank officers need to be carried out intensively. The hope is that they can understand more deeply about the profile of MSMEs and educate a sharper market.

The purpose of this study was to determine the analysis of labor absorption in the Small and Medium Enterprises (MSME) sector in the industri tahu bulat CV. Macakal Pangan Sejahtera in Cipaku District, Ciamis Regency.

\section{Theoretical review}

\section{The Concept of Labor and Wage}

Workers are people of working age who are ready to do work, including those who are already working, those who are looking for work, those who are in school, and those who take care of the household (MT Rionga and Firdaus, 2007: 2). According to Law Number 33 of 2019, the workforce is everyone who is able to do work to produce goods and or services both to meet their own needs and for the community. Labor absorption is the acceptance of labor actors to carry out their duties properly or the 
existence of a situation that describes the availability of workers or job opportunities to be filled by job seekers (Todaro, 2003: 404-406).

Efforts to expand employment opportunities to absorb labor can be carried out in two ways: (1) Industrial development, namely the type of industry that is laborintensive in nature which can absorb a relatively large number of workers in the industry, including the home industry. (2) Through various public works projects, such as the construction of waterways, dams, and bridges. Employment problems are experienced by many countries, including Indonesia (Jannes, 2005: 39). This arises due to several factors such as low job opportunities, low economic growth and so on. Each country is trying to overcome this problem in various ways, for example by increasing economic growth, and improving the quality of education.

Each country has different employment problems including Indonesia, the following problems often arise from Indonesian employment: (1) The problem of low quality of labor arises due to low levels of education, both formal and non-formal education. The low level of education usually occurs due to the economic capacity of the Indonesian people who have not been able to take higher education. As a result, when entering the age of the workforce, the problem of low quality of labor arises. (2) Low number of job opportunities. The low number of job opportunities arises as a result of low community productivity so that the number of employment opportunities is not proportional to the number of the workforce. If the number of the workforce is not proportional to the number of jobs, it will cause unemployment problems.

Wages are payments obtained by various forms of services provided and provided by employers to workers (Sadono Sukirno, 2005: 350). Meanwhile, according to T. Gilarso (2003: 211) wages are defined as remuneration for the production factors of human labor, which broadly includes salaries, honoraria, overtime pay, allowances, and others. More clearly the notion of wages is described in Law No. 13 of 2003 concerning employment. Article 1 of the Law states that wages are workers' rights which are received and expressed in the form of money as a reward from the employer or employer to workers which are determined and paid according to a work agreement, agreement, or statutory regulations, including allowances for workers and his family for a job and/or service that has been or will be performed.

Components of Labor Wages consist of: (1) Basic Wages; a basic remuneration that has been paid to workers according to the level or type of work whose amount is determined based on the agreement. (2) Facilities; enjoyment in a tangible form because of a special nature or to improve the welfare of workers. Examples: pick-up and drop-off facilities, free feeding, canteen facilities. (3) Bonuses; payments received by workers from the company's profits or because of achievements.

There are several methods or systems used to calculate the amount of wages and the method of payment, including (1) wages by merit (deductible wages). In this way, the amount of remuneration is directly related to work performance, because the amount of wages depends on the number of results achieved in a certain time. This method can only be applied if the work can be measured quantitatively. (2) Time wage. This system bases wages on the length of time the worker works for the employer, which can be calculated hourly, daily, weekly or monthly. This system is mainly used 
for types of work where the results are difficult to calculate piece by piece. This method allows for good quality work because employees are not in a hurry, but need supervision and regulation to ensure employees actually work during working hours. (3) Wholesale wages. The piece rate system is remuneration paid for a job that is contracted out. This method of calculating wages is often used in a job completed by a group of workers. For all work, a fee is determined, which is then divided between the implementers. For example for building construction, making wells and others. (4) Premium wages. This wage system is a combination of time wages and piece wages. Basic wages for normal performance based on time or number of results. If an employee achieves more than that, he is given a premium. Premiums can also be given for example to save time and raw materials, good product quality and so on. (5) Profitsharing wage. This system is widely used in agriculture and in family businesses, but employees also receive a share of the company's net profits, and are even given shares in the company where they work so that they become owners and receive profit sharing (T. Gilarso, 2003: 216-217).

In remuneration policy, the main objective is a policy that bases wages on the contribution of employees' energy and thoughts. The structure of wages or salaries represents a formal system of scales for this purpose. This system differentiates in payments which are considered to show the same difference in forms of work. Productivity increments or adjustments for improvement factors that relate wages or salaries to are made according to the company's progress average.

Wage policies are generally made to: (1) There is payment of wages/salaries that are sufficient to ensure family life in normal circumstances. (2) Conducting differentiation of remuneration or remuneration awards in differences in skills, responsibilities, effort and working conditions. (3) Conducting a remuneration or remuneration in accordance with the increase in work or work efficiency given to enhance the life force of employees. (4) Conducting a remuneration or payroll development according to the company's financial stability. Several important factors that affect the amount of wages received by employees, namely supply and demand for employees, labor organization, ability to pay, productivity, cost of living, and government regulations (Manullang, 1974: 163).

\section{The Concept of Micro small and Medium Enterprises}

According to Law Number 20 of 2008 concerning Micro, Small and Medium Enterprises, what is meant by: (1) Micro-enterprises are productive businesses owned by individuals and/or individual business entities. (2) Small business is a productive economic business that stands alone, which is carried out by individuals or business entities that are not subsidiaries or branches of companies that are owned, controlled, or become a part, either directly or indirectly, of medium-sized businesses. (3) Medium business is a productive economic business that stands alone, which is carried out by individuals or business entities that are not subsidiaries or branches of companies that are owned, controlled, or become a part either directly or indirectly with small businesses or large businesses with total assets. net income or annual sales (Law Number: 20 of 2008).

The principles of empowering Micro, Small and Medium Enterprises according to Law Number 20 of 2008 include: (1) Growing independence, togetherness, and 
entrepreneurship for Micro, Small and Medium Enterprises to work on their own initiative. (2) The realization of a public policy that is transparent, accountable, and just. (3) Business development based on regional potential and market oriented in accordance with the competence of Micro, Small and Medium Enterprises. (4) Increasing the competitiveness of Micro, Small and Medium Enterprises. (5) Implementation of integrated planning, implementation, and control. (6) Law Number 20 of 2008 determines the objectives of Micro, Small and Medium Enterprises Empowerment, among others, namely: (a) Realizing a balanced, developing, and just national economic structure. (b) Grow and develop the ability of Micro, Small and Medium Enterprises to become strong and independent businesses. (c) Increasing the role of Micro, Small and Medium Enterprises in regional development, job creation, income distribution, economic growth, and alleviating people from poverty (Suhardi, 2012: 34).

\section{Methods}

This research is descriptive-qualitative analysis and the research method used is descriptive-analytical method. This research was conducted from March 2020 to November 2020. This research was conducted in the CV. Macakaal Pangan Sejahtera, Cipaku District, Ciamis Regency. The source of the data that the researcher collects is using primary and secondary data sources. The data collection technique used in this research is observation. The instruments used in this research are interviews, field notes, and documentation. The analytical method used in this research is the Constant Comparative Method with a data reduction process. Data reduction means summarizing, choosing important things, looking for themes and patterns and discarding unnecessary ones (Sugiyono, 2009: 338).

\section{Results and Discussion}

CV. Macakal Pangan Sejahtera is located on Jalan Raya Ciamis-Kawali Rt.o3 Rw.09, Hamlet Warung Distance, Muktisari Village, Cipaku District, Ciamis Regency, West Java Province. Judging from the geographical location with an area of 928.23 Ha, CV. Macakal Pangan Sejahtera is a rural area with heterogeneous community conditions, both social and economic factors. The topography of Muktisari Village in general is hilly with an altitude of $500 \mathrm{~m} / \mathrm{dpl}$, so if it is related to the theory of German scientists, namely Junghuhn in the division of vegetation based on the height of the earth, it can be interpreted that Muktisari Village is included in the lowland category with hot area characteristics.

The population of Muktisari Village based on the latest data from the 2015 Population Census was 6,189, in 2014 it was 6,145, in 2013 it was 6,146, in 2012 it was 6,078 . Education is one of the basic capital of development. So that education is an investment (capital) in the future. In Muktisari Village in 2012 - 2015, the number of teachers and students has increased every year. In 2015, there were 170 teachers, with 27 PAUD students, 153 TK/TPA, 147 SD, 256 MI, and 376 SMKs. 
The challenges faced in the development of community welfare include the process of Globalization and Industrialization as well as the prolonged Economic and Political Crisis. The perceived impacts include the growing and expanding weight, number and complexity of various social problems. With regard to the development of the situation and conditions of employment in Muktisari Village until the end of 2015, it still showed a conducive situation, although on the other hand there were still limited job opportunities and a large number of job seekers. This situation is becoming increasingly difficult to control as a result of the economic crisis and rising fuel prices.

The large number of job seekers in Muktisari Village is a result of the addition of a new workforce and termination of employment (PHK). This condition continues at various layers and levels of strategic business sectors that absorb a lot of workers. This situation seems to have contributed greatly to the number of job seekers that were not previously projected. The total workforce in 2015 was 2,969 people. The number of job seekers who can be channeled and placed in companies and other types of work is 2,055 people, while the remaining 914 people have not found work.

In terms of education, high school graduates rank the highest from the percentage of job seekers who are successfully placed to the total job seekers, which is by education level reaching 55 percent. In terms of employment, the number of workers placed has increased compared to the previous year, while the number of registered job seekers has decreased. The Macakal Tofu Industry was established in 2009. Initially, Macakal only produced tofu with ingredients to be sold to other factories that had already produced round tofu. Then, in 2010 Macakal started to produce round tofu due to the high demand from consumers. Since then, macakas have continued to grow rapidly because their round tofu products are superior to other round tofu factories.

In 2010, Macakal only had a business license in the form of a single business license. Then, in 2015 Macakal obtained a halal certificate from the MUI, and in early 2020 Macakal became a legal entity, under the name CV. Macakal Pangan Sejahteraal. This research was conducted from October 28 to November 4, 2020. The data collection used observation. The instruments used are field notes and interviews with respondents as well as the owner of the CV. Macakal Pangan Sejahteraal.

Industri tahu bulat CV. Macakal Pangan Sejahtera was established in 2009. At first, Macakal only produced tofu ingredients to be sold to other factories that had already produced round tofu. In 2010, Macakal started to produce round tofu due to many requests from consumers. Since then, Macakal has continued to grow rapidly because its round tofu products are superior to other round tofu factories. Tofu is famous for its macakal products which are durable and have a delicious taste. Durable here does not use preservatives but prioritizes cleanliness in every production process. The initial capital to set up a factory is Rp. 50,000,000, - for the main building, and Rp. 20,000,000, - for operational costs and the purchase of soybeans. In 2009, the demand for round tofu increased, at that time macakas only produced round tofu around 5000 to 10,000 eggs per day, in 2015 to $2019 \mathrm{CV}$. Macakaal can produce as much as $1,000,000$ round tofu grains per day.

However, at the beginning of 2020 until now the demand for round tofu has decreased drastically due to the increasing number of competitors so that sales have decreased. The process of making round tofu begins with preparing tofu ingredients 
first, then press the tofu to reduce the water content in the tofu, after the water content decreases, then the tofu can be mixed with the mixed spices, stir the tofu and spices until evenly distributed using a mixer machine, after that Tofu is printed in a round shape using human hands or manually. Along with the times, the current rounding process already uses machines with a ratio of one machine equal to 20 workers.

Marketing knows round from CV. Macakal has reached the islands of Sumatra, Java, Bali, and Kalimantan by using delivery services, such as buses, trains, and planes. Although the production of round tofu is not as much as in 2015 to 2019, round tofu is still in demand because round tofu is people's food at an affordable price. The key to creating quality food products is cleanliness and discipline in everything. If the work tools used are clean, the products will be more durable, if the employees are disciplined to work according to the production flow, the products produced will be of high quality. Currently, employees of CV. Macakal numbered 136 people with details of 56 employees milled, 79 people round tofu production and 1 technician.

The wage system that applies to CV. Macakal is a once a week wholesale system. Employee wages can exceed the UMR of Ciamis Regency, sometimes it can be less than the UMR of Ciamis Regency. Depends on the amount of production per day. The following table is the average wage for employees of the CV. Macakal Pangan Sejahtera:

Table. Average Employee Wages CV. Macakaal Pangan Sejahtera

\begin{tabular}{|c|c|c|c|}
\hline No & Field of Work & $\begin{array}{l}\text { Average Employee Wage } \\
\text { per day }\end{array}$ & $\begin{array}{l}\text { Average Employee Wage } \\
\text { per month }\end{array}$ \\
\hline 1. & Press & Rp. 100.000,- & Rp. 2.600.000,- \\
\hline 2. & Balo/Mixer & Rp. 80.000,- & Rp. 2.080.000,- \\
\hline 3. & Geleng Manual & Rp. 20.000,- & Rp. 520.000,- \\
\hline 4. & Geleng/ Machine operator & Rp. 70.000,- & Rp. 1.820.000,- \\
\hline 5. & Packing & Rp. 60.000,- & Rp. 1.560.000,- \\
\hline
\end{tabular}

Source: CV. Macakaal Pangan Sejahtera, 28-10-2020.

From the table above, it can be concluded that the average income of CV. Macakal exceeds the UMR of Ciamis Regency, and some are less than the UMR of Ciamis Regency. Employees of the press division earn an average of Rp. 100.000,- per day with about 5 hours working hours, employees of the balo or mixer division earn an average of Rp. 80,000,- per day with about 5 hours working hours, manual shove employees only get Rp. 20,000 per day, with a working hour of about 2 hours, machine operator employees earn an average of Rp. 70,000, - per day with about 5 hours of work, packing employees earn an average of Rp. 60.000, - per day with working hours of about 5 hours. The difference in wages for each field of work is due to the different levels of difficulty of each job.

Employment status in CV. Macakal are permanent employees and temporary employees or piece work. CV. Macakal does not carry out an employee recruitment program but only runs a refresher system or job exchange.

One of the reasons employees stay working at CV. Macakal is a sufficient wage, and because of the needs of the workers. Being an employee of CV. Macakal, of course, you must have criteria, namely employees who are subjective, have honesty, are tenacious, and are disciplined at work. The following are some of the assets owned by CV. Macakaal Pangan Sejahtera, among others: (1) Land and buildings, in the form of 
two milling factories (production of tofu ingredients), and two places for grinding mills (production of round tofu). (2) Production equipment, in the form of 10 presses, 12 mixers, and 3 modern shaking machines. (3) Vehicles, in the form of 4 pick up cars and 2 box cars.

Every company, of course, has obstacles and experiences obstacles in running their business. According to the Big Indonesian Dictionary (2002: 385) obstacles are obstacles or obstacles. CV. Macakas also have obstacles in carrying out their business activities. First, Human Resources (HR) starting from the level of Directors, Managers, to Employees who are still lacking in company management skills. Second, waste management which until now has not been able to be utilized and has always been a difficult problem to solve. Currently, the handling of round tofu production waste is still being disposed of to a waste collection point.

Based on the results of data collection and data analysis conducted, there are important findings related to research, including Capital, Wages, Human Resources (HR), and Waste. Capital is the most important part in creating a job, including Micro, Small and Medium Enterprises (MSMEs). If the capital issued is small, the business generated will also be small, whereas if the capital issued is a lot, the business generated will also receive high profits. Even though the entrepreneur spends a lot of capital, it is not necessarily a profit if the entrepreneur cannot manage his business properly. In running a business, it is necessary to have skills, skills, have broad insight, know business risks, and need to have high education to face market competition.

From the results of the study, that CV. Macakal is brave enough to create a business that only has a capital of Rp. 70,000,000,-. The business undertaken is not based on their own desires but on market demand. Thus, entrepreneurs can take advantage of the opportunities that are in front of their eyes, thus achieving a turnover of around Rp. 4,800,000,000.- per year.

The Ciamis Regency Wage Council sets the Ciamis Regency Minimum Wage in 2020 of Rp. 1,475,792, - while the wages received by employees of CV. Macakaal Food Prosperity reached Rp. 2.600.000,-. Thus, there is a considerable difference between the UMR in Ciamis Regency and the CV. Macakaal. It can be said that the wages of CV. Macakal exceeds the UMR of Ciamis Regency. In essence, humans who work for a company want compensation in return for services and this reward is called wages or salaries. Wages received by employees will affect morale and work productivity. If the wages given are relatively small, it will affect or reduce morale and consequently work productivity will decrease, and vice versa.

Wages are the main element in calculating production costs and components in determining the cost of goods that can determine the survival of the company. If a company pays too high it will result in a high cost of goods and if the wages are too low, it will make it difficult for the company to find workers. Wages are not the only motivation for employees to excel, but wages are also one of the important motivations that encourage employees to excel, so that the level of salary given will affect employee performance and loyalty.

Human Resources at CV. Macakal Pangan Sejahtera is still weak in skills and company management. Human Resources (HR) as the first and main factor in the 
development process and the achievement of company goals. If the company already has large capital, advanced technology, abundant natural resources but there are no human resources who can manage and utilize them, it will not be possible to achieve success in achieving the goals of a successful company. Therefore, the importance of the role of HR in the company is needed as an element of controlling the success of the company.

To increase competitiveness, companies must strive to improve HR performance by increasing expertise and skills to prepare HR for promotions and solving problems faced by the company. Improving the performance of human resources can be done through education, training, and focusing on several types of skills and expertise that are relatively similar and carried out in the short term, while the HR development process is more oriented towards improving skills and expertise that is broader and diverse and can be carried out in a variety of long-term ways.

Waste is part of the problem for CV. Macakaal Pangan Sejahtera which still can't be finished. One of them is the impact of smelly waste, liquid waste, and solid waste. Tofu waste contains high protein so that consequently it causes exhaust gas in the form of Ammonia or Nitrogen and Sulfur which is unpleasant and disturbing to health. Until now, there is still no way out of the risk of the smell, while on the other hand, tofu products are already a favorite food that must always be consumed by the small community up to the upper class.

The negative impact caused by the tofu factory threatens further business continuity on the availability of tofu for the community, because it is threatened with closure or prohibited from operating. However, CV. Macakal Pangan Sejahtera is lucky because it already has a business license in the form of a single business license, has a halal certificate from MUI, and is also a legal entity. Tofu industrial waste is waste generated in the process of making tofu and washing soybeans. The waste generated is in the form of solid waste and liquid waste. The impact of solid waste on the environment has not yet been felt because it can be used for animal feed, but liquid waste will cause a foul odor and if it is dumped directly into the river it will pollute the river. The resulting liquid waste contains suspended or dissolved solids, will undergo physical, chemical, and biological changes that will produce toxic substances or create a medium for the growth of germs, which can be in the form of disease germs or other germs that are harmful to the tofu itself or the human body.

Absorption of labor from 2009 to 2019 has employed around 250 employees, and currently, along with low production, there are 136 active employees. There are more male workers, namely 103 people with a presentation of $75 \%$, while female workers are 33 people with a percentage of 25\%. Factors Affecting Labor Absorption in Tofu Round CV. Macakal Pangan Sejahteraal are (1) factors of living necessities; (2) the factor of the absence of other jobs in Muktisari Village, Cipaku District; (c) the factor of low education level, in this case there are still employees at CV. Macakal who only graduated from elementary school, and there is also a junior high school graduate.

The number of workers in CV. Macakal Pangan Sejahtera based on the level of education, it can be observed that the number of workers based on the level of education is 37 people with elementary education with a presentation of $27 \%$, workers 
with junior high school education level as many as 49 people with a presentation of $36 \%$, workers with a high level of education SMA education as many as 46 people with a presentation of $34 \%$, and a workforce at the university level as many as 4 people with a presentation of $3 \%$.

The role of Micro, Small and Medium Enterprises (MSMEs) in the economy in Cipaku District can be seen from: (1) their position to assist in economic activities, (2) large job providers, (3) encouraging the development of local economic activities and community empowerment, (4) creators of new markets and sources of innovation. The results showed that there were analyzes found based on observations and interviews, including positive and negative aspects. The positive aspect are (1) CV. Macakal Pangan Sejahtera is able to absorb 136 employees and help the economy of the community in Muktisari Village, Cipaku District, Ciamis Regency. (2) The existence of a CV. The Prosperous Food Macakal can reduce the unemployment rate in Muktisari Village, Cipaku District, Ciamis Regency. (3) Employee wages CV. The Prosperous Food Macakal exceeds the UMR of Ciamis Regency. The negative aspects are (1) There is a decrease in the number of employees, in 2009-2019 it was able to absorb 250 workers while in 2020 it was only able to absorb 136 workers. (2) The decrease in the number of employees, one of which is due to the low demand for goods due to the emergence of new competitors. (3) With less demand for goods, business owners reduce the cost of spending on employee wages by reducing employee work rations. (4) The decrease in the number of employees was also due to a small supply of goods. (5) Currently, the company's finances are not smooth (lost) and income is decreasing.

The reduced amount of tofu production has an impact on employee wages because the wage system in the company is a wholesale system. This means that employee wages are determined by the amount or at least the amount of tofu production. In 2020 production did experience a drastic decline which resulted in employee wages not matching their needs, so that some employees slowly resigned and looked for jobs with higher wages.

\section{Conclusion}

Based on the results of data analysis and discussion that has been described, it can be concluded that: (1) Employment from 2009 to 2019 has employed about 250 employees, and currently, along with low production, leaving 136 active employees employee people. There are more male workers, namely 103 people with a presentation of $75 \%$, while female workers are 33 people with a percentage of $25 \%$. (2) The role of Micro, Small and Medium Enterprises (MSMEs) in the economy in Cipaku District can be seen from: (1) their position to assist in economic activities, (2) large job providers, (3) encourage the development of local economic activities and empowerment society, (4) creators of new markets and sources of innovation. (3) Analysis of Labor Absorption in the MSME Sector in the Industri tahu bulat CV. Macakaal Pangan Sejahtera has positive and negative aspects, including the following: a. Positive Aspects; (1) CV. Macakal Pangan Sejahtera is able to absorb 136 employees and help the economy of the community in Muktisari Village, Cipaku District, Ciamis Regency. (2) The existence of a CV. The Prosperous Food Macakal can reduce the unemployment rate in Muktisari Village, Cipaku District, Ciamis Regency. (3) Wages of employees CV. The Prosperous 
Food Macakal exceeds the UMR of Ciamis Regency. b. Negative Aspects; (1) There is a decrease in the number of employees, in 2009-2019 it was able to absorb 250 workers while in 2020 it was only able to absorb 136 workers. (2) The decrease in the number of employees, one of which is due to the low demand for goods due to the emergence of new competitors. (3) With less demand for goods, the business owner reduces the cost of spending on employee wages by reducing the employee's work share. (4) The decrease in the number of employees was also due to a small supply of goods. (5) Currently, the company's finances are not smooth (lost) and income has decreased.

\section{REFERENCES}

Agung, Ahmad. (2020). Ekonomi Koperasi dan UMKM. Bandung: Manggu Makmur Tanjung Lestari.

Amiaty, Ratna E. (2001). Kredit Bagi UMKM Antara Mitos dan Realitas. Diambil dari http://www.unisosdem.org/article_detail.php

Ananta \& Aris. (1985). Masalah Penyerapan Tenaga Kerja, Prospek dan Permasalahan Ekonomi Indonesia. Jakarta: Sinar Harapan.

Badan Pusat Statistik. (2009). Profil Usaha Mikro kecil. Jakarta.

Danim, Sudarwan. (2003). Ekonomi Sumber Daya Manusia. Bandung: CV Pustaka Setia.

Husaini \& Purnomo. (2008). Metodologi Penelitian Sosial. Jakarta: PT. Bumi Aksara.

Manullang. (1974). Manajemen Personalia. Jakarta: Ghalia Indonesia.

Moleong, Lexy J. (2007). Metodologi Penelitian Kualitatif. Bandung: PT. Remaja Rosdakarya.

Muhadjir. (1996). Metodologi Penelitian Kualitatif. Yogyakarta: Rake Sarasin.

Nazir, M. (1988). Metode Penelitian. Jakarta: Ghalia Indonesia.

Sukirno, Sadono. (2005), Mikro Ekonomi, Teori Pengantar (Edisi 3). Jakarta: PT. Raja Grafindo Persada.

Sukirno, Sadono. (2010). Mikro Ekonomi Teori Pengantar. (Edisi 3). Jakarta: Rajawali Pers.

Sudarsono dkk. (1988). Ekonomi Sumber Daya Manusia. Universitas Terbuka Jakarta: Karunia Jakarta.

Sugiyono. (2005). Metode Penelitian Administrasi. Bandung: Alfabeta.

Suhardi, et.al. (2012). Hukum Koperasi Usaha Mikro Kecil dan Menengah di Indonesia. Jakarta: PT.Akademia.

Sumarsono, Sonny. (2003). Ekonomi Manajemen Sumberdaya Manusia dan Ketenagakerjaan. Yogyakarta: Graha Ilmu.

Gilarso, T. (2003). Pengantar Ilmu ekonomi. Yogyakarta: Kanisius.

Wawa. (2005). Ironi Pahlawan Devisa. Jakarta: PT. Kompas Media Nusantara. 
